\title{
Chemosymbiotic bivalves contribute to the nitrogen budget of seagrass ecosystems
}

\author{
Ulisse Cardini $\mathbb{D}^{1,2,3} \cdot$ Marco Bartoli $\mathbb{D}^{3,4} \cdot$ Sebastian Lücker $\mathbb{D}^{5} \cdot$ Maria Mooshammer $\mathbb{D}^{1,10} \cdot$ Julia Polzin $\mathbb{D}^{1}$. \\ Raymond W. Lee ${ }^{6} \cdot$ Vesna Micić $^{7} \cdot$ Thilo Hofmann $\mathbb{D}^{7} \cdot$ Miriam Weber $^{8,9} \cdot$ Jillian M. Petersen (D) $^{1}$
}

Received: 31 January 2019 / Revised: 10 July 2019 / Accepted: 19 July 2019 / Published online: 8 August 2019

(c) The Author(s) 2019. This article is published with open access

\begin{abstract}
In many seagrass sediments, lucinid bivalves and their sulfur-oxidizing symbionts are thought to underpin key ecosystem functions, but little is known about their role in nutrient cycles, particularly nitrogen. We used natural stable isotopes, elemental analyses, and stable isotope probing to study the ecological stoichiometry of a lucinid symbiosis in spring and fall. Chemoautotrophy appeared to dominate in fall, when chemoautotrophic carbon fixation rates were up to one order of magnitude higher as compared with the spring, suggesting a flexible nutritional mutualism. In fall, an isotope pool dilution experiment revealed carbon limitation of the symbiosis and ammonium excretion rates up to tenfold higher compared with fluxes reported for nonsymbiotic marine bivalves. These results provide evidence that lucinid bivalves can contribute substantial amounts of ammonium to the ecosystem. Given the preference of seagrasses for this nitrogen source, lucinid bivalves' contribution may boost productivity of these important blue carbon ecosystems.
\end{abstract}

\section{Introduction}

Shallow-water chemosynthetic symbioses are widespread where decomposition of organic matter produces sulfide [1]. However, their relevance for ecosystem functioning has received limited attention due to the assumption that chemosynthesis plays a minor role in shallow-water ecosystems. Recent studies are challenging this assumption [2-4].

Supplementary information The online version of this article (https:// doi.org/10.1038/s41396-019-0486-9) contains supplementary material, which is available to authorized users.

Ulisse Cardini

ulisse.cardini@szn.it

$\triangle$ Jillian M. Petersen

petersen@microbial-ecology.net

1 University of Vienna, Centre for Microbiology and Environmental Systems Science, Division of Microbial Ecology, Vienna, Austria

2 Integrative Marine Ecology Department, Stazione Zoologica Anton Dohrn, National Institute of Marine Biology, Ecology and Biotechnology, Napoli, Italy

3 Marine Research Institute, University of Klaipeda, Klaipeda, Lithuania

4 Department of Life Sciences, University of Parma, Parma, Italy
In seagrass sediments, bivalves of the family Lucinidae consume sulfide through their chemosynthetic symbionts, allowing more plant growth while relying on the seagrass to stimulate sulfide production by free-living sulfate-reducing microorganisms [3]. Still, we know little about nutrient cycling in lucinid bivalves at both the organism and the ecosystem scale. Most studies to date have focused on carbon (C) fixation by the symbionts and transfer to the host $[5,6]$ or on the additional contribution of filter feeding to host nutrition [7]. Nitrogen $(\mathrm{N})$ metabolism has received far less attention until recently, when dinitrogen $\left(\mathrm{N}_{2}\right)$ fixation by chemosynthetic symbionts was shown to be possible in

5 Department of Microbiology, Institute for Water and Wetland Research, Radboud University, Nijmegen, The Netherlands

6 School of Biological Sciences, Washington State University, Pullman, WA, USA

7 University of Vienna, Centre for Microbiology and Environmental Systems Science, Department of Environmental Geosciences, Vienna, Austria

8 HYDRA Marine Sciences GmbH, Sinzheim, Germany

9 HYDRA Field Station Elba, Campo nell'Elba (LI), Italy

10 Present address: Department of Environmental Science, Policy, and Management, University of California, Berkeley, CA, USA 
two lucinid species [8,9]. Concurrently, chemosynthetic symbioses can, to varying degrees, gain their $\mathrm{N}$ from ammonium $\left(\mathrm{NH}_{4}{ }^{+}\right)$, nitrate, or dissolved free amino acids in their environment [10-12], with the symbionts being able to recycle $\mathrm{N}$ waste compounds within the symbiosis [13]. Surprisingly, although these studies attest to the expanded $\mathrm{N}$ metabolic versatility of chemosynthetic symbioses, the significance of lucinid bivalves in contributing to their ecosystem $\mathrm{N}$ budget has been largely overlooked. Since the lucinid symbionts have a versatile $\mathrm{C}$ and $\mathrm{N}$ metabolic repertoire, being able to fix inorganic $\mathrm{C}$ or grow heterotrophically, and to take up various nitrogen forms [8], they might provide lucinid bivalves with a distinct advantage over nonsymbiotic filter-feeding bivalves, while boosting their role in the biogeochemistry of seagrass ecosystems.

\section{Methods}

We studied a lucinid bivalve (Loripes orbiculatus) in the seagrass (Posidonia oceanica) sediments of Elba Island (Italy) during two field expeditions in April (spring) and October (fall) 2016. P. oceanica tends to consume porewater nutrients (particularly nitrogen) during the growth phase (spring and summer), which are therefore depleted in fall, while sulfide accumulates as a result of leaf burial and decomposition. To check if this was true for our study site, we analyzed porewater inorganic nutrient concentrations (dissolved inorganic nitrogen-DIN and dissolved inorganic phosphorus-DIP) down to $60 \mathrm{~cm}$ below the sediment surface, with a resolution of $5 \mathrm{~cm}$. Stable isotope probing with ${ }^{13} \mathrm{C}-\mathrm{NaHCO}_{3}{ }^{-}$and ${ }^{15} \mathrm{~N}-\mathrm{N}_{2}$ was used to quantify $\mathrm{C}$ and $\mathrm{N}_{2}$ fixation by the chemosynthetic symbionts. Exogenous sulfide was not added to the incubation seawater as our primary goal was to investigate environmentally driven differences in physiology in both seasons. An isotope pool dilution (IPD) experiment with ${ }^{15} \mathrm{~N}-\mathrm{NH}_{4} \mathrm{Cl}$, was conducted in October to quantify gross and net $\mathrm{NH}_{4}{ }^{+}$fluxes by the bivalve symbiosis. The IPD technique has not yet been applied in marine symbiosis research. This technique involves labeling the nutrient pool of interest (in our case by adding ${ }^{15} \mathrm{NH}_{4}{ }^{+}$). By quantifying the relative proportion of heavy and light isotopes in the nutrient pool, and the change in concentration over time, gross production (i.e., mineralization) and consumption (i.e., immobilization) rates can be calculated. Finally, elemental and natural stable isotope analyses $\left(\delta^{13} \mathrm{C}\right.$ and $\delta^{15} \mathrm{~N}, \mathrm{C}: \mathrm{N}$ ratio; symbiotic tissue mass index, SMI; and gill total S content) were carried out to study the stoichiometric and isotopic niche (as proxies of the ecological niche) of host and symbiont under the two contrasting seasons. Individual $\delta^{13} \mathrm{C}$ and $\delta^{15} \mathrm{~N}$ values of symbiont-bearing and nonsymbiotic tissues were analyzed to compare isotopic niche spaces of symbionts and host in April and October. For more details on all methods see the Supplementary Methods.

\section{Results and discussion}

The biogeochemistry of $P$. oceanica sediments is highly influenced by the seagrass seasonal growth, leaf burial, and decay by microorganisms. P. oceanica growth shows a late spring maximum and a fall minimum [14]. The plant tends to consume porewater nutrients (particularly nitrogen) during the growth phase (spring and summer), which are therefore depleted in fall, while sulfide accumulates as a result of leaf burial and decomposition [15]. Our porewater profiles confirm this pattern, with higher DIN concentrations and DIN: DIP ratios in April compared with October $(p<0.01$; Fig. S1).

L. orbiculatus is able to supplement its diet with filter feeding on a seasonal basis [7]. Here we show that not only the host, but also the chemoautotrophic symbionts may modulate their metabolic activities according to the availability of external (or recycled) resources. C fixation by the symbionts was roughly 10-fold higher in October compared with April $\left(p<0.001\right.$; Fig. 1a). $\mathrm{N}_{2}$ fixation, measured for the first time here in a chemosynthetic symbiosis using the ${ }^{15} \mathrm{~N}-\mathrm{N}_{2}$ method, also increased in October, although not significantly (Fig. 1b). The boost in autotrophy was potentially mediated by higher sulfur energy storage within the symbionts ( $p<0.01$; Fig. S4).

The increased $\mathrm{C}$ fixation rates drove the $\mathrm{C}: \mathrm{N}$ ratio of the symbionts higher, but not of the host $(p<0.001$; Fig. 2a), attesting to the stoichiometric flexibility of the autotrophic
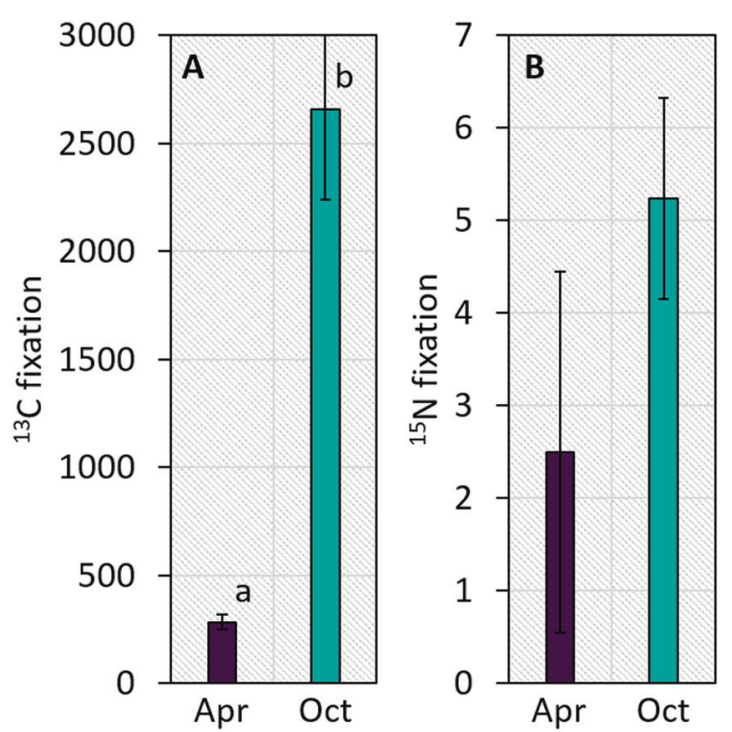

Fig. 1 Results from ${ }^{13} \mathrm{C}-\mathrm{HCO}_{3}{ }^{-}$and ${ }^{15} \mathrm{~N}-\mathrm{N}_{2}$ isotope probing experiments: a Carbon and $\mathbf{b}$ dinitrogen fixation by the microbial symbionts $\left(\mathrm{nmol} \mathbf{C}\right.$ (or N) g gill tissue $\mathrm{e}^{-1} \mathrm{~h}^{-1} \pm \mathrm{SE}, \mathrm{n}=5$ ). Sampling points are color-coded in purple (April) and cyan (October). Different lowercase letters indicate significant differences $(p<0.05$, PERMANOVA) 


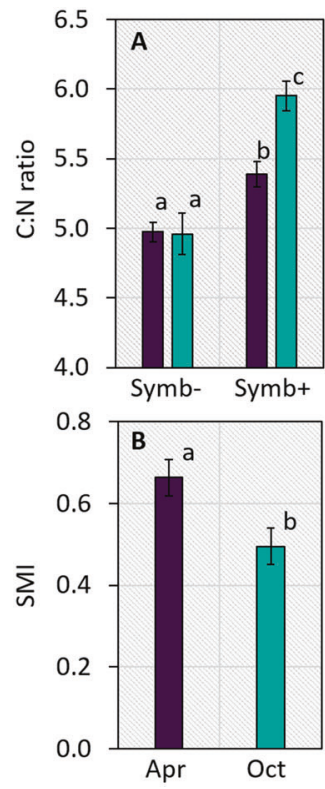

Fig. 2 Results from freshly sampled bivalve specimens: a C:N ratio $( \pm \mathrm{SE}, n=10)$ of symbiont-free (Symb-) and symbiont-hosting (Symb+) animal tissues; b Symbiotic tissue mass index-SMI. The SMI indicates the proportion of symbiont-hosting gill biomass $\left(\mathrm{mg} \mathrm{mm}^{-1} \pm \mathrm{SE}, n=10\right.$; see Supplementary Methods for details on how this index was calculated); $\mathbf{c}$ Biplot of the natural abundance of ${ }^{13} \mathrm{C}$ and ${ }^{15} \mathrm{~N}$ isotopes showing

partner in the symbiosis and the homeostasis of the heterotrophic host [16]. However, the distribution of bi-variate Bayesian ellipses shows that the natural isotopic niche of the sulfide-oxidizing symbionts was significantly larger in the samples collected in October (Fig. S2; i.e., lower trophic specialization), which may indicate a history of mixotrophic metabolism of the endosymbionts, consistent with the presence of a complete tricarboxylic acid cycle and transporters for uptake of organic compounds in their genome [8].

The proportion of symbiont-hosting gill biomass (SMI) was lower in October $(p<0.05$; Fig. $2 b)$. At the same time, there was a strong overlap in $\mathrm{C}$ isotopic niche of host and symbionts, indicating a match in their $\mathrm{C}$ source, while there was a mismatch in April (Fig. 2c). These results could be explained by a flexible nutritional mutualism. Under nutrient rich/high productivity conditions in April, when labile organic matter in seagrass sediments is highest [17], the host relies more on mixotrophy through filter feeding. Under nutrient depleted/low productivity but sulfide-rich conditions in October, the symbiosis shifts toward relying more on the symbionts as a source of energy. Our observation that symbiont $\mathrm{C}$ fixation rates were ten times higher in October compared with April is consistent with this theory.

Filter-feeding bivalves that do not host chemosynthetic symbionts enter a "dormant" state in summer, possibly due to food limitation [18 and references therein]. The ability to harvest energy throughout the summer and fall by relying on symbiont primary production when food availability is the total amount of niche space occupied (total area, dashed polygons) and the isotopic niche width (standard ellipse area, solid ellipses) as proxies of trophic specialization of symbiont-free (squares) and symbiont-hosting (triangles) animal tissues. Sampling points are colorcoded in purple (April) and cyan (October). Different lowercase letters indicate significant differences $(p<0.05$, PERMANOVA)

low would provide lucinid bivalves with a distinct advantage over nonsymbiotic filter-feeding bivalves. While more targeted approaches will be needed to conclusively verify this hypothesis, gross $\mathrm{NH}_{4}^{+}$production and consumption measured in October using IPD indicated that the symbiosis was indeed $\mathrm{C}$ limited, as bivalves consumed $\mathrm{NH}_{4}{ }^{+}$only when exposed to a source of labile organic C (Fig. S3).

The same experiments, using IPD on an invertebrate symbiotic animal for the first time to our knowledge, allowed us to quantify gross and net excretion rates contributed by the symbiosis to its surroundings. Net excretion by the bivalves was $\sim 15 \mu \mathrm{mol} \mathrm{NH_{4 }}{ }^{+} \mathrm{g}_{\mathrm{SFDW}}{ }^{-1} \mathrm{~h}^{-1}$ (Fig. S3), which is up to tenfold higher compared with $\mathrm{NH}_{4}{ }^{+}$excretion rates reported for other nonsymbiotic marine bivalves [19] and testifies to the potential of these chemosynthetic symbioses to underpin ecosystem functioning by nitrogen provisioning.

\section{Conclusions}

In this study, we show that $L$. orbiculatus likely has a flexible nutritional mutualism, in which host and symbionts cycle between a looser trophic association and a tight chemoautotrophic partnership, changing nutritional strategy according to the environmental conditions. Further, we report that under Climiting conditions these chemosymbiotic bivalves can excrete substantial amounts of $\mathrm{NH}_{4}{ }^{+}$to the environment. In seagrass sediments, lucinids and their endosymbionts are not only 
relevant for their role in sulfide detoxification [3], but can also provide the plant's preferred $\mathrm{N}$ form [20], thus contributing to the productivity of these important blue carbon ecosystems.

Acknowledgements The authors thank Margarete Watzka for her assistance with sample preparation for IRMS analyses, and Alexandra Belitz, Nathalie Elisabeth, Christian Lott and the team of the HYDRA Field Station Elba for their assistance during fieldwork and/or lab activities. Augusto Passarelli is kindly acknowledged for his help with the inorganic nutrient analyses. The Petersen laboratory is supported by a Vienna Research Groups for Young Investigators grant from the Vienna Science and Technology Fund (WWTF). UC and MB are supported by the project INBALANCE (LMT, grant 09.3.3-LMT-K-712-010069), funded by the European Social Fund according to the activity 'Improvement of researchers' qualification by implementing world-class R\&D projects'. SL is supported by the Netherlands Organisation for Scientific Research (NWO, grant 016.Vidi.189.050).

Author contributions UC contributed to the design of the research project, conducted the fieldwork and performed all the experiments, analyzed the data, and wrote the manuscript. $\mathrm{MB}$ conducted ${ }^{15} \mathrm{~N}-\mathrm{NH}_{4}{ }^{+}$measurements at the membrane inlet mass spectrometer, and provided critical input for data interpretation. RL conducted bulk stable isotope measurements on bivalve tissues and provided critical input for data interpretation. SL provided guidance for GC-MS measurements of ${ }^{15} \mathrm{~N}$ enrichments in seawater samples. MM assisted in designing the IPD experiment and provided critical input for data interpretation. JP contributed to the project during fieldwork and sample analyses. VM and TH conducted gill total S measurements of bivalve specimens. MW assisted with the organization and conduction of all fieldwork activities. JMP contributed to the design of the research project, data interpretation, and manuscript production.

\section{Compliance with ethical standards}

Conflict of interest The authors declare that they have no conflict of interest.

Publisher's note: Springer Nature remains neutral with regard to jurisdictional claims in published maps and institutional affiliations.

Open Access This article is licensed under a Creative Commons Attribution 4.0 International License, which permits use, sharing, adaptation, distribution and reproduction in any medium or format, as long as you give appropriate credit to the original author(s) and the source, provide a link to the Creative Commons license, and indicate if changes were made. The images or other third party material in this article are included in the article's Creative Commons license, unless indicated otherwise in a credit line to the material. If material is not included in the article's Creative Commons license and your intended use is not permitted by statutory regulation or exceeds the permitted use, you will need to obtain permission directly from the copyright holder. To view a copy of this license, visit http://creativecommons. org/licenses/by/4.0/.

\section{References}

1. Dubilier N, Bergin C, Lott C. Symbiotic diversity in marine animals: the art of harnessing chemosynthesis. Nat Rev Microbiol. 2008;6:725-40.

2. Higgs ND, Newton J, Attrill MJ. Caribbean spiny lobster fishery is underpinned by trophic subsidies from chemosynthetic primary production. Curr Biol. 2016;26:3393-8.
3. van der Heide T, Govers LL, de Fouw J, Olff H, van der Geest M, van Katwijk MM, et al. A three-stage symbiosis forms the foundation of seagrass ecosystems. Science. 2012;336:1432-4.

4. de Fouw J, Govers LL, van de Koppel J, van Belzen J, Dorigo W, Sidi Cheikh MA, et al. Drought, mutualism breakdown, and landscape-scale degradation of seagrass beds. Curr Biol. 2016;26:1051-6.

5. Distel DL, Felbeck H. Pathways of inorganic carbon fixation in the endosymbiont-bearing lucinid clam Lucinoma aequizonata. Part 2. Analysis of the individual contributions of host and symbiont cells to inorganic carbon assimilation. J Exp Zool. 1988;247:11-22.

6. Herry A, Diouris M, Le Pennec M. Chemoautotrophic symbionts and translocation of fixed carbon from bacteria to host tissues in the littoral bivalve Loripes lucinalis (Lucinidae). Mar Biol. 1989;101:305-12.

7. van der Geest M, Sall AA, Ely SO, Nauta RW, van Gils JA, Piersma T. Nutritional and reproductive strategies in a chemosymbiotic bivalve living in a tropical intertidal seagrass bed. Mar Ecol Prog Ser. 2014;501:113-26.

8. Petersen JM, Kemper A, Gruber-Vodicka H, Cardini U, van der Geest M, Kleiner M, et al. Chemosynthetic symbionts of marine invertebrate animals are capable of nitrogen fixation. Nat Microbiol. 2016;2:16195.

9. König S, Gros O, Heiden SE, Hinzke T, Thürmer A, Poehlein A, et al. Nitrogen fixation in a chemoautotrophic lucinid symbiosis. Nat Microbiol. 2016;2:16193.

10. Lee RW, Robinson JJ, Cavanaugh CM. Pathways of inorganic nitrogen assimilation in chemoautotrophic bacteria-marine invertebrate symbioses: expression of host and symbiont glutamine synthetase. J Exp Biol. 1999;202:289-300.

11. Lee RW, Thuesen EV, Childress JJ. Ammonium and free amino acids as nitrogen sources for the chemoautotrophic symbiosis Solemya reidi Bernard (Bivalvia: Protobranchia). J Exp Mar Biol Ecol. 1992;158:75-91.

12. Hentschel U, Cary SC, Felbeck H. Nitrate respiration in chemoautotrophic symbionts of the bivalve Lucinoma aequizonata. Mar Ecol Prog Ser. 1993;94:35-41.

13. Kleiner M, Wentrup C, Lott C, Teeling H, Wetzel S, Young J, et al. Metaproteomics of a gutless marine worm and its symbiotic microbial community reveal unusual pathways for carbon and energy use. Proc Natl Acad Sci USA. 2012;109:E1173-82.

14. Alcoverro T, Duarte CM, Romero J. Annual growth dynamics of Posidonia oceanica: contribution of large-scale versus local factors to seasonality. Mar Ecol Prog Ser. 1995;120:203-10.

15. Abadie A, Borges AV, Champenois W, Gobert S. Natural patches in Posidonia oceanica meadows: the seasonal biogeochemical pore water characteristics of two edge types. Mar Biol. 2017; 164:166.

16. Persson J, Fink P, Goto A, Hood JM, Jonas J, Kato S. To be or not to be what you eat: regulation of stoichiometric homeostasis among autotrophs and heterotrophs. Oikos. 2010;119:741-51.

17. Danovaro R, Fabiano M, Boyer M. Seasonal changes of benthic bacteria in a seagrass bed (Posidonia oceanica) of the Ligurian Sea in relation to origin, composition and fate of the sediment organic matter. Mar Biol. 1994;119:489-500.

18. Coma R, Ribes M. Seasonal energetic constraints in Mediterranean benthic suspension feeders: effects at different levels of ecological organization. Oikos. 2003;101:205-15.

19. Benelli S, Bartoli M, Racchetti E, Moraes PC, Zilius M, Lubiene I, et al. Rare but large bivalves alter benthic respiration and nutrient recycling in riverine sediments. Aquat Ecol. 2017;51:1-16.

20. Alexandre A, Hill PW, Jones DL, Santos R. Dissolved organic nitrogen: a relevant, complementary source of nitrogen for the seagrass Zostera marina. Limnol Oceanogr. 2015;60:1477-83. 